\title{
Study of Association of Pancreatitis with Hepatitis A in 1 - 15 Years Age Group in a Tertiary Care Hospital
}

\author{
Dillip Kumar Das ${ }^{1}$, Suprabha Shukla², Mangal Charan Murmu³ \\ 1, 2, 3 Department of Paediatrics, Srirama Chandra Bhanja Medical College, Cuttack, Odisha, India.
}

\section{ABSTRACT}

\section{BACKGROUND}

Hepatitis A is endemic in most countries, with frequent outbursts of minor and major outbreaks. The exact incidence of the disease is difficult to estimate because of the high proportion of asymptomatic cases. However, according to World Health Organization about 10 - 50 persons per 100,000 are affected annually. The Indian literature is replete with numerous reports of sporadic and epidemic occurrence of the disease in various cities. Acute pancreatitis is described as a complication in children in both the acute and convalescent phase. Our aim was to find out the frequency of acute pancreatitis considering clinical features, biochemical changes (serum amylase and lipase) and ultra-sonographic evidence of pancreatic involvement in paediatric population by estimating serum amylase and lipase level in paediatric population who were admitted with the diagnosis of hepatitis-A.

\section{METHODS}

The present prospective study was conducted in the S V P PG Institute of Paediatrics and S C B Medical College, Cuttack, Odisha, India which is a premier referral institute of Eastern India.

\section{RESULTS}

Overall, the proportion of patients with raised levels of serum amylase in the hepatitis A group was $41.67 \%(n=15)$. Comparing these values with the control group shows that the rise in serum amylase levels is statistically significant (' $p$ ' value $<0.05$ ). Hyperamylasaemia and hyperlipasaemia were associated with hepatitis A patients.

\section{CONCLUSIONS}

The rise of pancreatic enzymes was statistically significant in hepatitis A and may be considered as a causative agent of subclinical pancreatitis with biochemical and radiological changes.

\section{KEY WORDS}

Pancreatitis, Hepatitis, Serum Amylases, Lipase
Corresponding Author: Dr. Mangal Charan Murmu, QR, No.A/4, Doctors Colony, Shishubhaban, Chandinichowk, Cuttack, India.

E-mail: mangal74murmu@yahoo.co.in

DOI: $10.14260 /$ jemds/2021/1

How to Cite This Article:

Das DK, Shukla S, Murmu MC. Study of association of pancreatitis with hepatitis a in 1 - 15 years age group in a tertiary care hospital. J Evolution Med Dent Sci 2021;10(01):1-6,

10.14260/jemds/2021/1

Submission 10-08-2020,

Peer Review 09-11-2020,

Acceptance 16-11-2020,

Published 04-01-2021.

Copyright (C) 2021 Dillip Kumar Das et al. This is an open access article distributed under Creative Commons Attribution License [Attribution 4.0 International (CC $B Y 4.0)]$ 


\section{BACKGROUND}

Hepatitis A was formerly known as infectious hepatitis or epidemic jaundice. It is an acute infectious disease caused by hepatitis A virus. The disease is heralded by nonspecific symptoms such as fever, chills, headache, fatigue, generalized weakness and aches and pains followed by anorexia, nausea, vomiting, dark urine and jaundice. ${ }^{1}$ Hepatitis $A$ is endemic in most countries, with frequent outbursts of minor and major outbreaks. The exact incidence of the disease is difficult to estimate because of the high proportion of asymptomatic cases. However according to WHO about 10 - 50 persons per 100,000 are affected annually. ${ }^{2}$ The exact incidence of Hepatovirus A (HAV) in India is not known. The Indian literature is replete with numerous reports of sporadic and epidemic occurrence of the disease in various cities. ${ }^{3}$

Sood et al. ${ }^{4}$ presented a case of a 12-year-old Indian girl with history of fever, generalized malaise and jaundice for 8 days, severe epigastric pain associated with nausea and vomiting for 1 day. Investigation revealed leukocyte count: 15 $\times 109$ / L, direct bilirubin: $3.47 \mathrm{mg} \mathrm{/} \mathrm{dL}$, aspartate aminotransferase (AST): $198 \mathrm{U} / \mathrm{L}$ (normal 0 - $38 \mathrm{U} / \mathrm{L}$ ), alanine aminotransferase (ALT): $249 \mathrm{U} / \mathrm{L}$ (normal 0 - $39 \mathrm{U} /$ L), alkaline phosphatase: $459 \mathrm{U} / \mathrm{L}$ (normal 39 - $117 \mathrm{U} / \mathrm{L}$ ), serum amylase: $2069 \mathrm{U} / \mathrm{dL}$ (normal: $0-220 \mathrm{U} / \mathrm{dL}$ ), serum lipase: $2149 \mathrm{U} / \mathrm{ml}$ (normal: 0 - $190 \mathrm{U} / \mathrm{ml}$ ), IgMHAV (immunoglobulin M Hepatovirus A) antibodies are present. Plain film of abdomen showed distended small bowel loops with no fluid levels. Ultrasonography of abdomen revealed slightly enlarged pancreas with normal echogenicity. On supportive treatment, patient started showing respond. After 15 days, her biochemical and ultrasonographic parameters returned to normal.

Pancreatitis is defined as inflammation of the pancreas resulting in acinar cell injury caused by the destructive effects of pancreatic enzymes. It is a relatively infrequent illness in pediatrics, affecting males and females equally and involving all ages. The aetiology of pancreatitis in pediatrics is diverse in nature, with a grossly unpredictable clinical course and prognosis. The diagnosis requires a high index of suspicion and should be considered in all children admitted with abdominal pain and elevated pancreatic enzymes. The disease is classified into acute and chronic forms or single and recurring episodes, respectively. 5

Acute pancreatitis as a complication of acute hepatitis A infection has been noted rarely in older individuals. ${ }^{6}$ There are few case reports of acute pancreatitis in patients with hepatitis A, suggesting that serious pancreatic disease may represent a complication of hepatitis A infection.4,6-12 Up till now, only few prospective studies have been reported on pancreatic abnormalities during hepatitis-A in paediatric population. The present study was performed in S V P PG Institute of paediatrics and S C B Medical College, Cuttack, Odisha, India, which is a referral tertiary paediatric institution, to evaluate the frequency of acute pancreatitis considering clinical features, biochemical changes (serum amylase and lipase) and ultrasonic evidence of pancreatic involvement in paediatric population who were admitted with the diagnosis of hepatitisA.

\section{Objectives}

1. To find out the association of acute pancreatitis in patients with hepatitis A of age group 1 to 15 years.

2. To determine the frequency of pancreatitis in patients with hepatitis A of age group 1 to 15 years and to compare the results with those of controls.

\section{METHODS}

After obtaining clearance from institutional ethical committee present prospective study was conducted at S V P PG Institute of Paediatrics and S C B Medical College, Cuttack, Odisha, India, to find out the frequency of acute pancreatitis considering clinical features, biochemical changes (serum amylase and lipase) and ultrasonographic evidence of pancreatic involvement in paediatric population by estimating serum amylase and lipase level in paediatric population who were admitted with the diagnosis of hepatitis A. Children with fever for at least 3 days and / or jaundice of age group $1-15$ years and of both sexes were selected who qualified for inclusion criteria and were allocated to study and control groups. Serum amylase and lipase level was done in all patients. The study period was from January 2017 to December 2019. Total number of cases qualified for our study is 36 .

No ethnic, socioeconomic, cultural discriminations were considered during selection of the children for this study.

Children under study were divided into two groups -

- Study Group (Hepatitis A) - Those who had clinical features strongly suggestive of hepatitis $A$ and subsequently confirmed by estimating IgM HAV in serum.

- Control Group - Those who were admitted with fever and / or jaundice and subsequently diagnosed to have disease other than hepatitis A.

\section{Inclusion Criteria}

Children with following conditions were included in the study group -

\section{Study Group (Hepatitis A)}

Clinical features strongly suggestive of hepatitis A consisted of the following features in 1 to 15 years old children. 1) Sclera and skin show jaundice. 2) $\mathrm{H} / \mathrm{O}$ moderate fever, severe malaise, loss of appetite, nausea and upper abdominal pain. 3) Dark coloured urine. 4) Clay coloured stool. 5) Tender hepatomegaly. 6) Residence in a known history of hepatitis A in other family member or in the community. 7) No apparent source of infection like malaria especially falciparum, dengue, leptospirosis as a cause of jaundice. 8) Marked elevation of serum glutamic-oxaloacetic transaminase / serum glutamicpyruvic transaminase (SGOT / SGPT).

\section{Control Group}

Those who were admitted with fever and / or jaundice and subsequently diagnosed to have disease other than hepatitis A.

\section{Exclusion Criteria}

Study Group (Hepatitis A)

1) Past history of jaundice due to any hepatitis virus. 2) Past history of pancreatic, renal or salivary gland disease. 3) 
Children once enrolled for the study were not enrolled for second time in the study. 4) History of immunisation with hepatitis A vaccine. 5) History of any biliary tract disease, intake of toxin or drugs that causes hepatitis.

\section{Control Group}

1) Past history of hepatitis A. 2) Past history of pancreatic, renal, liver or salivary gland disease. 3) History of immunisation with hepatitis A. 4) Children once enrolled for the study were not enrolled for second time in the study.

The following clinical and laboratory data were recorded in all patients - Detailed history including drug history, past history of suffering from similar illness, immunisation history and family history of the concerned disease. Thorough clinical examination was done in each and every case.

The following laboratory investigations were done in all patients 1) haemoglobin, total leucocyte count, differential count, erythrocyte sedimentation rate, platelet, malarial parasite, 2) random blood sugar, serum urea, serum creatinine, sodium, potassium, calcium, 3) liver function test including total bilirubin (conjugated and unconjugated), serum glutamic-oxaloacetic transaminase, serum glutamicpyruvic transaminase (SGOT, SGPT) and alkaline phosphatase, 4) c-reactive protein, 5) serum amylase and lipase: 1st time recorded on the 1 st day of admission and 2 nd time recorded 10 days after, 6) chest X-ray (PA view), 7) straight X-ray abdomen, 8) Mantoux test, 9) urine for RE / ME and C / S, 10) Stools for RE / ME, 11) USG of the abdomen (especially pancreas)

- Special Test: For Hepatitis A: IgM anti HAV antibody.

- Serum amylase estimation: EPS - G7 method, serum lipase estimation: Turbidimetric method.

- Serum IgMHAV estimation: ELISA test.

- Interpretation of results: Colorimetric Method.

- Positive OD450 of sample, average OD450 of negative controls.

- Negative OD450 of sample, average OD450 of negative controls.

- Invalid if the OD of positive control is below 0.80, the result is invalid. In any event, repeat the test.

- Notes if the absorbance of negative controls is below 0.05, calculate it as 0.05 . If the absorbance of negative controls is above 0.05 , calculate it as its original value.

\section{Statistical Analysis}

Mean, ranges, standard deviation and frequency were used as descriptive statistics. $\mathrm{P}$ value $<0.05$ is taken as statistically significant.

\section{RESULTS}

\section{Control Group}

In the present study, there were 44 children who had a diagnosis other than typhoid fever or hepatitis A. Among 44 children 24 cases (54.54\%) were males and 20 cases (45.46 $\%)$ were females. The male-female ratio was 1.2: 1 . The mean age of children in this group was 9.52 years with a standard deviation of $10 \pm 0.50$. The age and sex wise distribution of children in control group are shown in table 1 below.

\begin{tabular}{|c|c|c|c|c|c|c|c|c|c|c|c|c|}
\hline \multirow{3}{*}{ Sex } & \multicolumn{6}{|c|}{ Age Group } & \multirow{2}{*}{\multicolumn{2}{|c|}{$\begin{array}{c}\text { Column } \\
\text { Marginal }\end{array}$}} & \multirow{2}{*}{\multicolumn{2}{|c|}{$\%$}} & \multicolumn{2}{|c|}{ Ratio } \\
\hline & \multicolumn{2}{|c|}{$\begin{array}{c}1-5 \\
\text { Years }\end{array}$} & \multicolumn{2}{|c|}{$\begin{array}{l}6-10 \\
\text { Years }\end{array}$} & \multicolumn{2}{|c|}{$\begin{array}{c}11-15 \\
\text { Years }\end{array}$} & & & & & \multirow[b]{2}{*}{$\begin{array}{l}\overline{0} \\
\stackrel{\Xi}{0} \\
0\end{array}$} & \multirow[b]{2}{*}{ 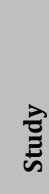 } \\
\hline & ర્ڤ & 总 & 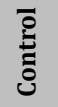 & $\sum_{\tilde{n}}^{\vec{E}}$ & כo & 冚 & Do & है & 홀 & 总 & & \\
\hline Male & 1 & 11 & 9 & 6 & 14 & 2 & 24 & 19 & 6.8 & 52.8 & 1.2 & 1.1 \\
\hline Female & 2 & 09 & 7 & 7 & 11 & 1 & 20 & 17 & 36.4 & 47.2 & 1 & 1 \\
\hline Total & 3 & 20 & 16 & 13 & 25 & 3 & 44 & 36 & 56.8 & - & - & - \\
\hline$\%$ & 6.8 & 55.56 & 36.4 & 36.11 & 56.8 & 8.33 & 100 & 100 & 100 & - & - & - \\
\hline & & $T a b$ & e 1. & lge Gr & $\overline{u p c}$ & $d S e x$ & Wise & ist & buti & & & \\
\hline
\end{tabular}

The above table shows that maximum number of cases under control group fall in the age group of 11 to 15 years and minimum number in the age group of 1 to 5 years.

\section{Disease Distribution in Control Group}

Of 44 control patients, the main final diagnostic groups were acute respiratory tract infection (ARI) (17 or $38.6 \%$ ), acute gastro-enteritis (AGE) (12 or $27.2 \%$ ), dysentery ( 9 or $20.6 \%$ ), tuberculosis (tb) (3 or $6.8 \%$ ), malaria (3 or $6.8 \%$ ).

\section{Study Group (Hepatitis)}

A diagnosis of hepatitis A was made in 36 children, out of whom 19 cases (52.8\%) were males and 17 cases (47.2.4\%) were females. The male-female ratio was 1.11:1. The mean age group of children in hepatitis A group was 5.92 years.

The maximum number of cases under hepatitis A group falls in the age group of 1 to 5 years and minimum number in the age group of 10 to 15 years. The above table 5 and chart- 5 shows that males are more affected than the female in hepatitis A group.

\begin{tabular}{|c|c|c|c|c|}
\hline \multicolumn{2}{|c|}{ Group } & Serum Amylase & No. of Patient & $\%$ \\
\hline A & A1 & Normal & 39 & 88.64 \\
\hline (Control) & A2 & $\begin{array}{c}\text { Raised but less than } 3 \text { times } \\
\text { the normal }\end{array}$ & 5 & 11.36 \\
\hline & B1 & Normal & 21 & 58.33 \\
\hline $\begin{array}{c}\text { B } \\
\text { (Study) }\end{array}$ & B2 & $\begin{array}{c}\text { Raised but less than } 3 \text { times } \\
\text { the normal }\end{array}$ & 11 & 30.56 \\
\hline$N=36$ & B3 & $\begin{array}{l}\text { Raised more than } 3 \text { times } \\
\text { the normal }\end{array}$ & 4 & 11.11 \\
\hline & & $\begin{array}{l}\text { parison of Serum Amyla } \\
(n=44) \text { and Study Grov }\end{array}$ & $\begin{array}{l}\text { se in the Cont } \\
p(n=36)\end{array}$ & roup \\
\hline
\end{tabular}

A total of 44 patients were included in the control group. of the 44 cases, only 5 patients had raised serum amylase levels at the time of initial assessment. They were divided into groups based on the magnitude of elevation of serum amylase depicted as follows -

- $\quad$ Normal value of serum amylase (39 cases: $88.64 \%$ ) (A1)

- Serum amylase rose to less than 3 times normal (5 cases: $11.36 \%$ ) (A2)

The magnitude of the rise in serum amylase levels in patients belonging to the group A2 varied from $103-153 \mathrm{U} /$ $\mathrm{L}$ with a mean value of $128 \pm 20.66 \mathrm{U} / \mathrm{L}$. On repeat evaluation of the serum amylase value after 10 days, 4 patients $(80 \%)$ had normal values while in 1 patient (20\%), the value remained raised to less than twice the normal. 
A total of 36 patients were included in the study group who were diagnosed as hepatitis A cases based on serology. Of the 36 hepatitis A patients, 21 patients had raised serum amylase levels at the time of initial assessment.

The cases were divided into groups based on the magnitude of elevation of serum amylase depicted as follows -

- $\quad$ Normal value of serum amylase (21 cases: $58.33 \%$ ) (B1)

- Serum amylase rose to less than 3 times normal (11 cases: $30.56 \%$ ) (B2)

- Serum amylase rose to more than 3 times the normal (4 cases: $11.11 \%$ ) (B3)

The magnitude of the rise in serum amylase levels in patients belonging to the group B2 varied from 123 - $293 \mathrm{U} /$ $\mathrm{L}$ with a mean value of $225 \pm 48.22 \mathrm{U} / \mathrm{L}$ and to the group B3 varied from $303-442 \mathrm{U} / \mathrm{L}$ with a mean value of $387 \pm 55.03$ $\mathrm{U} / \mathrm{L}$.

Thus, we find that in the hepatitis A group 15 patients had raised serum amylase values while in the control group only 5 had raised serum amylase levels. Using ' $z$ ' test, a ' $p$ ' value of less than 0.05 was obtained which was statistically significant i.e. hyperamylasemia was associated with a significant number of cases in those patients with hepatitis A compared to the controls.

Serum amylase levels were repeated in these 15 patients after 10 days. The results in the case group are as follows -

- $\quad$ Of the 11 patients included in the B2 group, 9 patients had values in the normal range while 2 had serum amylase value which was raised but was below twice the normal range.

- Of the 4 patients in group B3, 3 patients had values in the normal range while 1 had serum amylase value which was raised but was below twice the normal range.

- Hepatitis A patient shows mild elevation of serum amylase.

Analysis of serum lipase in the control group - None of the patients under control group showed any elevation of serum lipase.

\begin{tabular}{|cccc|}
\hline Group & Serum Lipase & No of Patients & $\mathbf{\%}$ \\
C1 & Normal & 19 & 52.78 \\
C2 & Raised but less than 3 times the & 10 & 27.78 \\
C3 & $\begin{array}{c}\text { Raised more than 3 times the normal } \\
\text { Raised but less than 3 times the } \\
\text { normal (n = 17) }\end{array}$ & 7 & 19.44 \\
\hline Table 3. Analysis of Serum Lipase in Patients with Hepatitis $\boldsymbol{A}(\boldsymbol{n}=\mathbf{3 6})$ \\
\hline
\end{tabular}

The magnitude of the rise in serum lipase levels in patients belonging to the group $\mathrm{C} 2$ varied from $35-87 \mathrm{U} / \mathrm{L}$ with a mean value of $57 \pm 16.98 \mathrm{U} / \mathrm{L}$ and to the group C 3 varied from $107-143 \mathrm{U} / \mathrm{L}$ with a mean value of $122 \pm 14.27 \mathrm{U} / \mathrm{L}$.

Serum lipase levels were repeated in these 17 patients after 10 days. The results in the hepatitis A group are as follows -

- Of the 10 patients included in the $\mathrm{C} 2$ group, 9 patients had values in the normal range while 1 had serum lipase value which was raised but was below twice the normal range.

- $\quad$ Of the 7 patients in group C3, 5 patients had values in the normal range while 2 had serum lipase value which was raised but was below twice the normal range.

17 hepatitis A patient shows raised serum amylase level on initial assessment but on repeat assessment done on day 10 , only 3 hepatitis A patients showed mild elevation of serum amylase.

\begin{tabular}{|cccccc|}
\hline \multirow{2}{*}{ Group } & \multicolumn{2}{c}{$\begin{array}{c}\text { Serum } \\
\text { Amylase }\end{array}$} & $\begin{array}{c}\text { Serum } \\
\text { Lipase }\end{array}$ & $\begin{array}{c}\text { No of } \\
\text { Patients }\end{array}$ & $\%$ \\
& normal & 39 & - & - & 88.64 \\
Control & $\uparrow$ & 5 & - & - & 11.36 \\
& $\uparrow$ & - & - & - & - \\
& normal & $21(58.33 \%)$ & $19(52.78 \%)$ & - & - \\
Hepatitis A & $\uparrow$ & $11(30.56 \%)$ & $10(27.78 \%)$ & - & - \\
& $\uparrow$ & $4(11.11 \%)$ & $7(19.44 \%)$ & - & - \\
D1 & & $\mathrm{N}$ & $\mathrm{N}$ & 19 & 52.77 \\
D2 & & $\uparrow \uparrow$ & $\uparrow \uparrow$ & 3 & 8.33 \\
D3 & & $\uparrow \uparrow$ & $\uparrow$ & 1 & 2.78 \\
D4 & & $\uparrow$ & $\uparrow \uparrow$ & 4 & 11.11 \\
D5 & & $\uparrow$ & $\uparrow$ & 7 & 19.4 \\
D6 & \multicolumn{5}{c}{ Table 4. Analysis of Serum Amylase and Lipase in } \\
\hline \multicolumn{5}{c}{ Hepatitis A Patient When Considered Together } \\
\hline
\end{tabular}

$[(\uparrow \uparrow)=$ more than 3 times the normal; $(\uparrow)=$ less than 3 times normal; $(-)=$ no rise]

$88.64 \%(n=39)$ patients under control group are of normal serum amylase level and $11.36 \%(n=5)$ shows mild elevation of serum amylase. In hepatitis A group, $58.33 \%$ ( $\mathrm{n}=$ 21) patients shows normal serum amylase, $11.11 \%(n=4)$ patients shows significant rise of serum amylase and mild rise of serum amylase (raised but less than 3 times normal) found in $30.56 \%(\mathrm{n}=11)$ patients. In the same group significant rise of serum lipase found in $19.44 \%(n=7)$ patients, mild rise of serum lipase found in $27.78 \%(n=10)$ patients and serum lipase level was normal in $52.78 \%(n=19)$ patients.

Hepatitis A patients were divided into groups based on the magnitude of elevation of both serum amylase and lipase when considered together depicted as follows -

- Both the serum amylase and lipase values were within normal range ( $\mathrm{n}=19: 52.77 \%$ ) (D1).

- Serum amylase and lipase was significantly raised (more than 3 times the normal) ( $n=3: 8.33 \%$ ) (D2).

- $\quad$ Either serum amylase or lipase was raised significantly (more than 3 times the normal) ( $\mathrm{n}=5: 13.89 \%$ ) (D3 \& 4).

- Both Serum amylase and lipase was raised mildly (less than 3 times normal) ( $\mathrm{n}=7: 19.4 \%$ ) (D5).

- Only mild rise of serum lipase (less than 3 times normal) ( $\mathrm{n}=2: 5.56 \%$ ) (D6).

\begin{tabular}{|cccc|}
\hline Group & $\begin{array}{c}\text { No. of Patients Showing } \\
\text { Abnormal Pancreas }\end{array}$ & $\begin{array}{c}\text { Total No. } \\
\text { of Patients }\end{array}$ & $\%$ \\
Control & 0 & 44 & 00.00 \\
Hepatitis A & 3 & 36 & 8.33 \\
\hline \multicolumn{4}{|c|}{ Table 5. Analysis of Ultrasonography of Abdomen } \\
in the Control Group, Typhoid Fever Patients \\
\hline
\end{tabular}

Only 3 cases ( $8.33 \%$ ) out of 36 hepatitis A patient shows bulky pancreas.

\section{DISCUSSION}

Among 36 children diagnosed to have hepatitis A, 19 cases (52.8\%) were male and 17 cases (47.2\%) were female. The mean age group of children in hepatitis A group was 5.92 years. The present study shows that maximum number of hepatitis A patients $(55.56 \% ; \mathrm{n}=20)$ fall in the age group of 1 
to 5 years and minimum number $(8.33 \% ; n=3)$ in the age group of 11 to 15 years.

This finding is corroborated with those obtained by Singh et al. ${ }^{13}$ in their study which showed the incidence of hepatitis A was highest among less than 5 years of age and declined progressively and significantly thereafter. The low incidence of Hepatitis A patient after 10 years of age $(8.33 \%$; $=3)$ may be explained by the fact that very high infection rates in the first few years of life and most of the population acquiring antibodies to HAV by 10 years of age as suggested by Batra et al. ${ }^{14}$

In our study hyperamylasaemia and hyperlipasaemia were recorded in $41.66 \%$ and $47.22 \%$ of patients with hepatitis A, respectively. Four patients $(11.11 \%)$ had serum amylase levels more than thrice the normal values while 7 patients (19.44\%) had serum lipase levels three times above the normal range. Only 3 patients $(8.33 \%)$ in this group had both serum lipase and amylase three times above the normal levels. Morphological alteration in the pancreas was present in all these three patients ( $8.33 \%)$. None of the patients with raised serum amylase and lipase value had significant clinical findings of acute pancreatitis. The mean serum amylase in patients with hepatitis A with pancreatic involvement was $268.2 \pm 76.54 \mathrm{U} / \mathrm{L}$ and the mean lipase value was $83.8 \pm 35.48$ $\mathrm{U} / \mathrm{L}$. Repeat serum amylase and lipase was done after 10 days which revealed that out of 15 patients $(41.66 \%)$ with raised serum amylase level only 3 of them (8.33\%) had persistently raised, whereas, 3 patient $(8.33 \%)$ out of 17 patient with raised serum lipase level had persistently raised but the repeat values were always less than three times the normal. The above noted finding may be explained by the fact that there may be some degree of cholestasis occurred in hepatitis A infection.

Very few studies have been done to confirm the association of hepatitis A with acute pancreatitis. Sporadic case reports have been documented in the existing literature. Therefore, it will be very difficult to compare the findings of the present study with the previous case reports available. However, it has been shown from the present study that there is indeed a correlation between pancreatic involvement and acute hepatitis A, although the incidence of acute pancreatitis clinically is absent.

Basaranoglu et al. ${ }^{7}$ reported a young woman with gallbladder sludge and acute pancreatitis due to acute hepatitis A (HAV). A magnetic resonance cholangiopancreatography revealed imaging features of an acute stage of pancreatitis and gallbladder wall thickness with coexisting sludge in the gallbladder lumen. HAV infection was diagnosed by the detection of immunoglobulin $M$ against HAV in the serum. In this case, they observed reversible changes in the hepatobiliary and pancreatic system, which was related to the severity of hepatic necro-inflammation. HAV associated pancreatitis may be due to the formation of biliary sludge during the acute phase of the viral illness.

Sood et al. ${ }^{4}$ presented a case of a 12-year-old Indian girl with history of fever, generalized malaise and jaundice for 8 days, severe epigastric pain associated with nausea and vomiting. IgMHAV antibodies were present. Ultrasonography of abdomen revealed slightly enlarged pancreas with normal echogenicity. On supportive treatment, patient started showing respond. After 15 days her biochemical and ultrasonographic parameters returned to normal.

Lopez Morante et al. ${ }^{11}$ reported a boy with fever and jaundice, with distended, tender abdomen and absent bowel sound. IgMHAV antibodies were present. The 24 hours urinary amylase content was $27,600 \mathrm{U}$ and the amylase / creatinine clearance ratio was $7.1 \%$ (normal < $5 \%$ ). On discharge, bilirubin and amylase returned to normal values.

Shrier et al. ${ }^{6}$ described a 4-year-old Korean girl who was admitted in hospital for intermittent severe supraumbilical pain radiating to periumbilical region for 1 day. On examination she was found to have jaundice, mild periumbilical tenderness with hepatomegaly. IgM and IgGHAV antibodies were present. Ultrasonography of abdomen revealed increased echogenicity and thickening of entire pancreas and a prominent pancreatic duct. Computed tomography scan showed a diffusely swollen pancreas. On supportive treatment, patient started showing respond from $4^{\text {th }}$ day. One month after discharge, ultrasonographically pancreas appeared normal. By 11 weeks of onset, liver functions and pancreatic enzyme findings were within normal limits.

Even if the mean elevation of serum amylase and lipase in our patients with hepatitis A was lower than that reported by others, $4,6-11$ in our prospective study, data confirm that hyperamylasaemia and hyperlipasaemia can be found in patients with hepatitis A.

The mechanism by which hepatitis A virus may cause pancreatitis is unknown. The cytopathic effect may be direct or it may be mediated through the patient's immune response. Animal studies of other viral infections and pancreatitis have suggested either direct inflammation and acinar cell destruction ${ }^{15,16}$ or edema of the ampulla of Vater causing obstruction of pancreatic outflow. ${ }^{17}$ When acute pancreatitis is associated with fulminating hepatitis, the virus may cause tissue damage directly, but there are several other factors which can play an important role in the development of pancreatitis and these include acute liver failure, hypotension and drug induced disease. These factors were not operated in our present study and the pancreatic damage could only have been caused by HAV. Autodigestion may play a role in potentiating pancreatic damage. ${ }^{18}$ In our study no coincidental causes of acute pancreatitis, such as alcohol abuse, gallstone disease, drug or toxin induced pancreatic injury, trauma, or anomalies of the pancreaticobiliary tree were evident.

\section{CONCLUSIONS}

Overall, the proportion of patients with raised levels of serum amylase in the hepatitis A group was $41.67 \%(n=15)$. Comparing these values with the control group shows that the rise in serum amylase levels is statistically significant (' $p$ ' value $<0.05$ ). The serum lipase levels' rise in the study group, hepatitis A group is statistically significant (' $p$ ' value is $<0.05$ ). On ultrasound, patients with viral hepatitis A who showed significant rise in serum amylase values, had evidence of bulky pancreas. 
Data sharing statement provided by the authors is available with the full text of this article at jemds.com.

Financial or other competing interests: None.

Disclosure forms provided by the authors are available with the full text of this article at jemds.com.

\section{REFERENCES}

[1] Park K. Viral Hepatitis, preventive and social medicine. $18^{\text {th }}$ edn. M/s Banarsidas Bhenot Publishers 2005: p. 167.

[2] World Health Organisation. Health situation in the South - East Asia region 1994-97. New Delhi: South East Asia Region 1999.

[3] Indian Council of Medical Research. Viral Hepatitis proceedings of the task force held on January 8, 1980. 1980.

[4] Sood A, Midha V. Hepatitis A and acute pancreatitis. J Assoc Physicians India 1999;47(7):736-7.

[5] Morinville VD, Husain SZ, Bai H, et al. Definitions of pediatric pancreatitis and survey of present clinical practices. J Pediatr Gastroenterol Nutr 2012;55(3):261-5.

[6] Shrier LA, Karpen SJ, McEvoy C. Acute pancreatitis associated with acute Hepatitis A in a young child. J Pediatr 1995;126(1):57-9.

[7] Basaranoglu M, Balci NC, Klor HU. Gallbladder sludge and acute pancreatitis induced by acute Hepatitis A. Pancreatology 2006;6(1-2):141-4.

[8] Davis TV, Keefe EB. Acute pancreatitis associated with acute Hepatitis A. Am J Gastroenterol 1992;87(11):164850.
[9] Mishra A, Saigal S, Gupta R, et al. Acute pancreatitis associated with viral Hepatitis: a report of six cases with review of literature. Am J Gastroenterol 1999;94(8):2292-5.

[10] Batra Y, Chakravarty S, Bhatt G. Severe acute pancreatitis associated with acute Hepatitis A: a case report. Trop Gastroenterol 2003;24(1):27-8.

[11] Morante AL, de Lope CR, San Miguel G, et al. Acute pancreatitis in Hepatitis A infection. Postgrad Med J 1986;62(727):407-8.

[12] Agarwal KS, Pulyel JM, Mathew A, et al. Acute pancreatitis with cholestatic Hepatitis: an unusual manifestation of Hepatitis A. Ann Trop Paediatr 1999;19(4):391-4.

[13] Singh J, Gupta S, Khare S, et al. A severe and explosive outbreak of Hepatitis B in a rural population in Sirsa district, Haryana, India: Unnecessary therapeutic injections were a major risk factor. Epidemiol Infect 2001;125(3):693-9.

[14] Batra Y, Bhatkal B, Ojha B, et al. Vaccination against Hepatitis A virus may not be required for schoolchildren in Northern India: results of a seroepidemiological survey. Bull World Health Organ 2002;80(9):728-31.

[15] Ursing B. Acute pancreatitis in Coxsackie B infection. Br Med J 1973;3(5879):524-5.

[16] Burch GE, Harb JM. Electron microscopic studies of viral pancreatitis in Coxackie B4 virus infected mice. Exp Mol Pathol 1979;31(1):23-35.

[17] Tsui CH, Burch GE, Harb JM. Pancreatitis in mice infected with Coxackievirus B1. Arch Pathol 1972;93(5):379-89.

[18] World Health Organisation. The world health report: report of the director general. WHO 1996. 